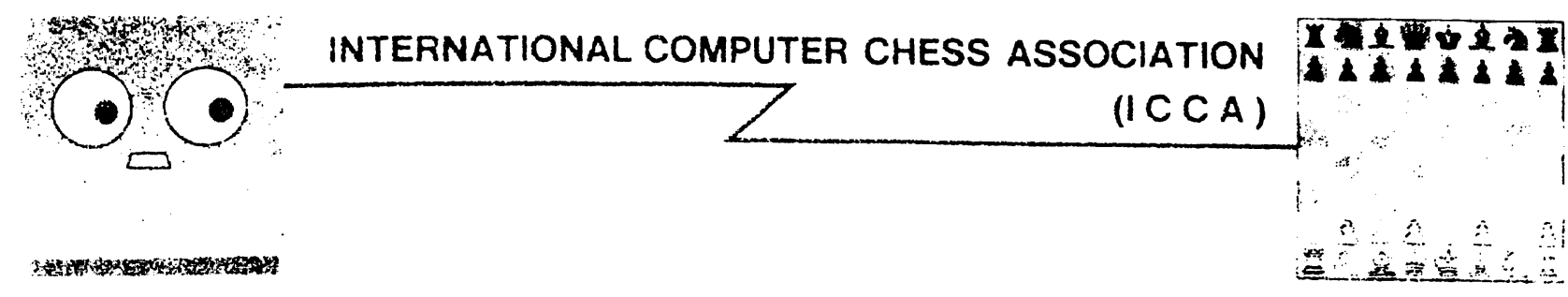

\title{
COA Newsletter
}

Vo1. 4 No. 1

May 1981

Copyright 1981, ICCA

\section{EDITORIAL}

ICCA has completed three years of existence and currently has 450 active members. It sponsored the Third World Computer Chess Championship last September in Linz, Austria. It will be sanctioning other tournaments in the near future. A world microcomputer tournament is planned for Hamburg, Germany in September. The Third European Computer Chess Championship will be held in Munich in october. The 12th ACM North American Tournament will be held in Los Angeles in November.

In this issue of the Newsletter we announce a new policy intended to encourage the growth of ICCA chapters all over the world. It provides a rebate of part of the membership fees to chapters with at least 20 members each.

Some of the articles in this issue include a report of the 1980 Microtournament in Stockholm, a report on a trip to the Soviet Union, and an analysis by Prof. Hans Berliner of how he defeated BELLE in a fascinating game last December. We look forward to contributions of articles by our readers, since without such material, we cannot produce an interesting publication for our members.
Editor: B. Mittman

Editorial Asst.: J. Cesal

Northwestern University

Evanston, Illinois 60201, USA

Finally, we are saddened by the recent death of a great supporter of computer chess, a charter member of ICCA, and a friend: Dr. Edward Lasker.

\section{B. Mittman \\ Editor}

\section{Table of Contents}

Editorial.................. 1 Dr. Edward Lasker, $1885-1981 \ldots \ldots .2$ Informal ICCA Meeting Held

in Chicago................. 3

Membership Information..............

ICCA Publications Board Formed... 3 ICCA Chapter Support Policy

Established................ 3

A brighter future for Soviet computer chess?.............4 4

Ex-World (Correspondence) Champ beats Current World (Computer)

Champ................... 8

Computer Chess at IFIP $80 \ldots \ldots \ldots 10$

Summary of the Stockholm Micro

1980 Tournament - Dec. 1980....12

Advances in Computer Chess 3....14

Tournament Announcements ........15 